\title{
OCTN2-mediated transport of carnitine in isolated Sertoli cells
}

\author{
Daisuke Kobayashi ${ }^{1,2}$, Akihiko Goto ${ }^{1}$, Tomoji Maeda ${ }^{1}$, Jun-ichi Nezu ${ }^{3}$, Akira Tsuji ${ }^{2}$ \\ and Ikumi Tamai ${ }^{1}$ \\ ${ }^{1}$ Faculty of Pharmaceutical Sciences, Tokyo University of Science, 2641 Yamasaki, Noda, Chiba 278-8510, Japan, \\ ${ }^{2}$ Faculty of Pharmaceutical Sciences, Kanazawa University, Kakuma, Kanazawa 920-1192, Japan and ${ }^{3}$ Chugai \\ Pharmaceutical Co. Ltd, Ibaraki, Japan \\ Correspondence should be addressed to I Tamai; Email: tamai@rs.noda.tus.ac.jp
}

\begin{abstract}
Carnitine is extensively accumulated in epididymis. Carnitine is also accumulated in testis at higher concentration than in the plasma and is used in spite of the presence of the blood-testis barrier. In this study, we examined the characteristics of carnitine transport in primary-cultured rat Sertoli cells, which constitute a part of the blood-testis barrier. Uptake of [ $\left.{ }^{3} \mathrm{H}\right]$ carnitine $(11.4 \mathrm{nM})$ from the basal side of Sertoli cells was $\mathrm{Na}^{+}$-dependent and was significantly decreased in the presence of $10 \mu \mathrm{M}$ (48.0 $\pm 7.4 \%$ of control) or $100 \mu \mathrm{M}$ unlabeled carnitine (14.6 $\pm 5.7 \%$ of control). Furthermore, the uptake was significantly inhibited in the presence of $100 \mu \mathrm{M}$ acetyl-L-carnitine, $100 \mu \mathrm{M}$ gamma-butyrobetaine or $500 \mu \mathrm{M}$ quinidine. In RT-PCR analysis, the high-affinity carnitine transporter OCTN2 was detected in rat whole testis tissue and primary-cultured Sertoli cells. In contrast, the low-affinity carnitine transporter $\mathrm{ATB}^{0,+}$ was detected in rat whole testis tissue, but not in primary cultured Sertoli cells. These results demonstrate that OCTN2 mediates carnitine supply to Sertoli cells from the circulation.

Reproduction (2005) 129 729-736
\end{abstract}

\section{Introduction}

Carnitine is essential for fatty acid oxidation, facilitating the transfer of an acyl group into mitochondria. Acyl-carnitine ester, which can pass through the inner membrane of mitochondria, is synthesized from carnitine and acylcoenzyme A by carnitine palmitoyltransferase I (CPT I). Acyl-carnitine ester is esterified to acyl-thioesters by CPT II and undergoes beta-oxidation in mitochondria (Ramsay et al. 2001). In male reproductive tissues, the concentration of carnitine is higher than that in plasma (Marquis \& Fritz 1965, Casillas 1972, Jeulin \& Lewin 1996), and carnitine is a key nutrient for sperm maturation (Casillas \& Chaipayungpan 1979) and motility (Hinton et al. 1981). Studies have shown carnitine concentration to be reduced in seminal fluid of infertile patients (Matalliotakis et al. 2000), and improvement of sperm motility and viability of spermatozoa was obtained by treatment with carnitine and acetylcarnitine (Vicari \& Calogero 2001). Carnitine is extensively accumulated in epididymis (Hinton et al. 1979). Additionally, carnitine is also used in testis and is accumulated in testis at high concentrations compared with plasma after administration of exogenous $\left[{ }^{3} \mathrm{H}\right]$ carnitine (Bremer 1983) in spite of the presence of the bloodtestis barrier (BTB).

Sertoli cells are one of the most important constituents of the BTB, which is present between the blood circulation and germ cells, and serves to protect germ cells from exposure to xenobiotics. The Sertoli cells also provide a route for the supply of various nutrients to germ cells to support spermatogenesis. Since hydrophilic nutrients can not readily cross the plasma membrane of Sertoli cells, selective membrane transporters for each nutrient are likely to be needed. Although carnitine is a zwitterionic hydrophilic compound at physiological $\mathrm{pH}$ and is essential for the maturation of sperm cells, the transport mechanism of carnitine across the BTB has not yet been clarified.

Five mammalian transporters (OCTN1, 2, 3, CT2 and $\mathrm{ATB}^{0,+}$ ) are known to be able to transport carnitine. We established that OCTN1 and OCTN2 transport carnitine (Tamai et al. 1998, 2000, Yabuuchi et al. 1999). OCTN2 is an $\mathrm{Na}^{+}$-dependent, high-affinity carnitine transporter (Sekine et al. 1998, Tamai et al. 1998, 2000, Wu et al. 1999) and is essential for the renal reabsorption of carnitine (Yokogawa et al. 1999, Tamai et al. 2001). Loss of function of OCTN2 as a result of mutation of the OCTN2 gene leads to systemic carnitine deficiency due to inability to maintain the required carnitine level in plasma (Nezu et al. 1999). Enomoto et al. (2002) cloned a testis-specific carnitine transporter CT2 from human testis. Mouse OCTN3 is also a testis-specific carnitine transporter (Tamai et al. 2000), but the amino acid sequence homology between CT2 and 
mouse OCTN3 is only about $32 \%$. So, the true homologue of CT2 in laboratory animals such as mice and rats remains to be clarified. On the other hand, Nakanishi et al. (2001) reported that the $\mathrm{Na}^{+}$- and $\mathrm{Cl}^{-}$coupled neutral and cationic amino acid transporter $\mathrm{ATB}^{0,+}$ transports carnitine with low affinity $(\mathrm{Km}=0.83 \pm 0.08 \mathrm{mM})$ compared with OCTN2 $(\mathrm{Km}=$ about $20 \mu \mathrm{M})$. Accordingly, there are several possible carnitine transporters that may function in Sertoli cells.

In the present study, we examined the mechanism of carnitine transport across the basolateral membranes of Sertoli cells using primary-cultured, rat testis-derived Sertoli cells.

\section{Materials and Methods}

\section{Materials}

$\mathrm{L}-\left[{ }^{3} \mathrm{H}\right]$ Carnitine $(80.0 \mathrm{Ci} / \mathrm{mmol})$ and $\left[\right.$ carboxyl- ${ }^{14} \mathrm{C}$ ]inulin $(2.5 \mathrm{mCi} / \mathrm{g})$ were purchased from Amersham Biosciences Corp. (Piscataway, NJ, USA) and American Radiolabeled Chemicals (St Louis, MO, USA) respectively. Collagenase and trypsin were obtained from Sigma Chemicals Co. (St Louis, MO, USA) and Becton Dickinson Microbiology Systems (Sparks, MD, USA) respectively. All other reagents, unless otherwise noted, were purchased from Sigma Chemical Co. or Wako Pure Chemical Industries Co. (Osaka, Japan).

\section{Preparation and primary culture of rat Sertoli cells}

Sertoli cells were isolated from 20-day-old Donryu rats (Saitama Experimental Animal Supply Co. Ltd, Saitama, Japan) according to the reported method (Dorrington \& Fritz 1975, Nagao 1989, Shiratsuchi et al. 1997). Briefly, testes were decapsulated, and seminiferous tubules were incubated in $35 \mathrm{ml}$ of $0.25 \%$ collagenase in phosphatebuffered saline (PBS) for $20 \mathrm{~min}$ at $37^{\circ} \mathrm{C}$ with occasional stirring. The seminiferous tubules were washed with serum-free F12-L15 medium, and then incubated with occasional gentle pipetting in $35 \mathrm{ml}$ of $0.25 \%$ trypsin in PBS for $20 \mathrm{~min}$ at $37^{\circ} \mathrm{C}$. F12-L15 medium was composed of a 1:1 mixture of Ham's F12 medium (ICN Biomedicals Inc., Irvine, CA, USA) and L-15 medium (ICN Biomedicals Inc.), containing $15 \mathrm{mM}$ HEPES, $10 \mathrm{unit} / \mathrm{ml}$ penicillin, $0.1 \mathrm{mg} / \mathrm{ml}$ streptomycin and $10 \%$ fetal bovine serum (FBS, Invitrogen, Carlsbad, CA, USA). Trypsin treatment was terminated by adding $5 \mathrm{ml}$ of FBS and $10 \mathrm{ml}$ of F12-L15 medium containing $10 \%$ FBS. The resultant cell suspension was filtered twice through four sheets of gauze to remove cell aggregates and tissue debris, after which the cells were collected by centrifugation $(300 \mathrm{~g} \times 10 \mathrm{~min})$. The cells were suspended in $30 \mathrm{ml}$ of F12-L15 medium containing $10 \%$ FBS and washed by centrifugation $(150 \mathbf{g} \times 10 \mathrm{~min})$. Finally, the cells were suspended in F12L15 medium containing 10\% FBS and passed once through nylon mesh $(70 \mu \mathrm{m}, \mathrm{BD}$ Biosciences, Bedford,
MA, USA). The isolated testicular cells were seeded into culture dishes (\#353003, BD Biosciences). Cells were grown in F12-L15 medium, containing $1 \mu \mathrm{g} / \mathrm{ml}$ norepinephrine, in a humidified incubator at $32.5^{\circ} \mathrm{C}$ for 3 days and at $37^{\circ} \mathrm{C}$ for 3 days. Germ cells floating on the surface of the co-culture of testicular cells were harvested by pipetting for RT-PCR analysis at 2 and 4 days after seeding. Sertoli cells were isolated after removal of the germ cells floating on the surface of the testicular cells. About $90 \%$ of the cells adhering to the culture dish were Sertoli cells as judged from Nile red (Molecular Probes Inc., Eugene, OR, USA) staining, which is a marker for Sertoli cells (Mather et al. 1990). Six days after seeding, the cultures reached confluence and were used for the transport experiments and the RT-PCR analysis. Germ and Sertoli cells cultured for 2 and 4 days at $32.5{ }^{\circ} \mathrm{C}$ were collected for RT-PCR analysis. For uptake experiments across the basolateral membrane of rat primary-cultured Sertoli cells, the cells were cultivated on 24-well Matrigel invasion chambers (BD Biosciences) at $32.5^{\circ} \mathrm{C}$ for 3 days and at $37^{\circ} \mathrm{C}$ for 3 days.

\section{Carnitine transport experiments}

Transport experiments in suspended primary-cultured rat Sertoli cells were performed as described in our previous study (Kato et al. 2005). Briefly, cells were harvested with a cell scraper and suspended in transport medium containing $137 \mathrm{mM} \mathrm{NaCl}, 5 \mathrm{mM} \mathrm{KCl}, 0.39 \mathrm{mM} \mathrm{NaHCO} \mathrm{Na}_{3}$, $0.44 \mathrm{mM} \quad \mathrm{KH}_{2} \mathrm{PO}_{4}, 0.95 \mathrm{mM} \mathrm{CaCl}, 0.8 \mathrm{mM} \mathrm{MgSO}_{4}$, $25 \mathrm{mM}$ D-glucose and $10 \mathrm{mM}$ HEPES, adjusted to $\mathrm{pH} 7.4$ after washing two times with the transport medium. The cell suspension was preincubated at $37^{\circ} \mathrm{C}$ for $20 \mathrm{~min}$ in the transport medium, then centrifuged. The resultant cell pellets were re-suspended in $200 \mu \mathrm{L}$ of transport medium containing L- $\left[{ }^{3} \mathrm{H}\right]$ carnitine to initiate the uptake. After $30 \mathrm{~min}$, the cell suspension was diluted with $800 \mu \mathrm{L}$ of ice-cold transport medium and centrifuged immediately $(7000 \mathrm{~g} \times 1 \mathrm{~min})$ to terminate the uptake reaction. Then, the cells were resuspended in ice-cold transport medium and obtained as the pellet after centrifugation. The resultant cell pellets were solubilized in $1 \mathrm{M} \mathrm{NaOH}$ and the cell-associated radioactivity was measured with a liquid scintillation counter (Aloka, Tokyo, Japan) using Cleasol-1 (Nacalai tesque, Kyoto, Japan) as a liquid scintillation fluid. $\mathrm{Na}^{+}$-free transport medium was prepared by replacing $137 \mathrm{mM} \mathrm{NaCl}$ and $0.39 \mathrm{mM} \mathrm{NaHCO}_{3}$ in the standard transport medium with $137 \mathrm{mM} \mathrm{N}$-methyl-D-glucamine $(\mathrm{NMG}) \mathrm{Cl}$ or $137 \mathrm{mM}$ lithium $\mathrm{Cl}$ and $0.39 \mathrm{mM} \mathrm{KHCO}_{3}$ respectively, and was used to assess the uptake in the absence of sodium ions.

For the basolateral membrane uptake experiments using Matrigel invasion chambers (BD Biosciences), the medium in the basolateral membrane side was replaced with transport medium containing L- $\left[{ }^{3} \mathrm{H}\right]$ carnitine after preincubation in transport medium for $20 \mathrm{~min}$. The apical-side medium was also replaced with transport medium. At the 
designated time, the cells on the invasion chamber were rapidly washed twice with ice-cold transport medium, then solubilized in $1 \mathrm{M} \mathrm{NaOH}$, and the cell-associated radioactivity was measured by means of a liquid scintillation counter. L- $\left[{ }^{3} \mathrm{H}\right]$ Carnitine uptake was corrected for nonspecific extracellular adhesion based on the apparent uptake of $\left[{ }^{14} \mathrm{C}\right]$ inulin, a membrane-impermeable marker.

\section{Permeation of $\left[{ }^{14} C\right]$ inulin and $L-\left[{ }^{3} \mathrm{H}\right]$ carnitine across Sertoli cells cultured on a Matrigel-coated invasion chamber}

Permeation of $\left[{ }^{14} \mathrm{C}\right]$ inulin and $\mathrm{L}-\left[{ }^{3} \mathrm{H}\right]$ carnitine was measured by using Sertoli cells cultured on a Matrigelcoated invasion chamber (BD Biosciences). After preincubation in transport medium for $20 \mathrm{~min}$, radio-labeled test compounds were added to the basolateral side and the appearance of radio-activity in the apical side was measured periodically.

\section{RNA isolation and RT-PCR}

Total RNA was extracted from cultured cells with the ISOGEN RNA extraction solution (Wako Pure Chemical Industries) according to the manufacturer's protocol. cDNA was prepared from the extracted RNA by means of reverse transcription with Improm-Il reverse transcriptase (Promega, Madison, WI, USA) and oligo (dT) primers according to the manufacturer's instructions. The cDNA was used for PCR amplification under the following conditions. Different sets of primers were designed and synthesized for PCR analysis of each gene. The primer pair used for amplifying OCTN1 was 5'-ACCTCAGTGGGTTACTTTGCTC-3' and 5'-CTCCGCTGTGAAGACGTACA-3', which generated a 297-bp OCTN1 PCR product. For OCTN2, 5'-TTTCGTGGGTGTGCTGATAGTCGC-3' and 5'-GTGGAAGGCGCAACAATCCCATT-3' generated a 487bp OCTN2 PCR product. For $\mathrm{ATB}^{0,+}, 5^{\prime}$-AGGTGTGGGAATCACGATG-3' and 5'-GTTCACTGGGAAGTTGTCCT-3' generated a 296-bp $\mathrm{ATB}^{0,+}$ PCR product. For M-CPT I, 5'CAGGCAAAGAGACAGACTTG-3' and 5' - CTTGCAGGAGATGAGAGTGA-3' generated a 434-bp M-CPT I PCR product. For L-CPT I, 5'- ACAGGTGGTTTGACAAGTCC' and 5'- TTGATCAAGCCTTTGCCGAAA-3' generated a 331-bp L-CPT I PCR product. Reactions were carried out under the following conditions: denaturing at $94{ }^{\circ} \mathrm{C}$ for $30 \mathrm{sec}$, annealing at $58^{\circ} \mathrm{C}$ for $30 \mathrm{~s}$ and extension at $72^{\circ} \mathrm{C}$ for $30 \mathrm{sec}$. Primer pairs used for amplifying PGK-1 were 5'- CCCTGTTGGGGTATTTGAATGGGA-3' and 5'- TTTCCATGCTGTCATGAACAGTGA-3', which generated a 555bp PGK-1 PCR product and for amplifying PGK-2 were 5'- CCCTGTTGGGGTATTTGAATGGGA-3' and 5'- TTTCTCCCTAGGAAGGACTGTGGG-3', which generated a 467bp PGK-2 PCR product (Mizuno et al. 1996). The conditions of PCR for PGK-1 and PGK-2 were denaturing at $94{ }^{\circ} \mathrm{C}$ for $30 \mathrm{~s}$ and annealing and extension simultaneously at $68{ }^{\circ} \mathrm{C}$ for $2 \mathrm{~min}$. PCR products were analyzed by agarose gel electrophoresis and visualized by staining with ethidium bromide.

\section{Western blotting for rat OCTN2 in testicular cells}

For Western blotting, rabbit anti-mOCTN2 polyclonal antibody was raised against a synthetic polypeptide with the sequence TRMQKDGEESPTVLKSTAF, corresponding to the carboxyl terminal of mOCTN2 (Tamai et al. 2000). The COOH-terminal of the rat homologue (TRTQKDGGESPTVLKSTAF) differs from the mouse sequence in two amino acid residues, $T$ at the third and $G$ at the eighth position, as shown in italics (Sekine et al. 1998, Wu et al. 1999), and we confirmed that the antimOCTN2 antibody recognized rOCTN2 (Tamai et al. 2001). The sample preparation and Western blot analysis were essentially the same as described previously (Tamai et al. 2000, 2004).

\section{Analytical methods}

Cellular protein content was determined according to the method of Lowry (Lowry et al. 1951) with bovine serum albumin as the standard. Cellular uptake was usually expressed as cell-to-medium ratio ( $\mu \mathrm{l} / \mathrm{mg}$ protein), which was obtained by dividing the uptake amount ( $\mathrm{pmol} / \mathrm{mg}$ protein) by the concentration of test compound in the transport medium $(\mu \mathrm{M}=\mathrm{pmol} / \mu \mathrm{l})$.

All data are expressed as means \pm S.E.M., and statistical analysis was performed with Student's $t$-test. The criterion of significance was taken to be $P<0.05$.

\section{Results}

\section{Transport of $L-\left[{ }^{3} \mathrm{H}\right]$ carnitine in primary-cultured Sertoli cells}

First, we measured the uptake of carnitine by suspended, primary-cultured Sertoli cells to examine whether a carnitine transport system was active in the cells. Uptake of $\mathrm{L}-\left[{ }^{3} \mathrm{H}\right]$ carnitine by the cells was decreased in the absence of $\mathrm{Na}^{+}$compared with that in the presence of $\mathrm{Na}^{+}$(Fig. 1). Therefore, it appears that an $\mathrm{Na}^{+}$-dependent carnitine transport system is functional in primary-cultured Sertoli cells.

Carnitine uptake at the basolateral membrane of Sertoli cells is the first step of carnitine permeation from the systemic circulation to the testis across the BTB. To evaluate carnitine uptake at the basolateral membrane, polarized Sertoli cells are required. As it is not easy to obtain monolayers of polarized Sertoli cells, we used Sertoli cells primary-cultured on the Matrigel-coated invasion chambers. First of all, we evaluated the polarization of the cells in terms of the formation of tight-junctions between the cells by measuring the permeability of a paracellular transport marker, inulin. Figure 2 shows the permeability of $\left[{ }^{14} \mathrm{C}\right]$ inulin from the basal to the apical side in the presence of Sertoli cells $\left(0.082 \pm 0.005 \mu \mathrm{l} / \mathrm{min} / \mathrm{cm}^{2}\right)$ and that 


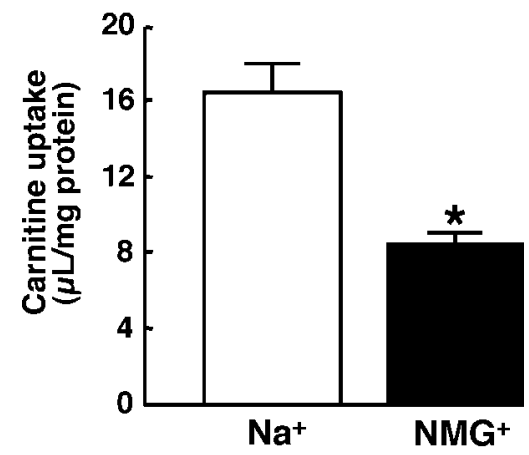

Figure 1 Sodium dependence of L-[ $\left.{ }^{3} \mathrm{H}\right]$ carnitine uptake by suspended rat primary-cultured Sertoli cells. Uptake of L- $\left[{ }^{3} \mathrm{H}\right]$ carnitine $(11.4 \mathrm{nM})$ by rat primary-cultured Sertoli cells in suspension was measured for $30 \mathrm{~min}$ in transport buffer ( $\mathrm{pH} 7.4$ ) in the presence (open column) or absence (closed column) of $\mathrm{Na}^{+}$. $\mathrm{Na}^{+}$was replaced with $\mathrm{N}$-methylglucamine $\left(\mathrm{NMG}^{+}\right)$. The cells were preincubated for $20 \mathrm{~min}$ at $37^{\circ} \mathrm{C}$ in the transport buffer $(\mathrm{pH}$ 7.4). Uptake was expressed as cell-to-medium ratio. Each result represents the mean \pm S.E.M. $(n=4)$. "Indicates a significant difference from the uptake in the presence of $\mathrm{Na}^{+}$ $(P<0.05)$.

in the absence of the cells $\left(0.425 \pm 0.050 \mu \mathrm{l} / \mathrm{min} / \mathrm{cm}^{2}\right)$. There is a substantial increase of the resistance to permeation in the presence of the cells owing to the formation of tight junctions. At the same time, the electrical resistance was $196.5 \pm 5.3 \Omega \cdot \mathrm{cm}^{2} \quad(n=18)$ in the presence of the cells after subtracting the electrical resistance in the cell-free chamber. The decrease of permeability of $\left[{ }^{14} \mathrm{C}\right]$ inulin and the increase of electrical resistance suggested that tight junctions are formed, based on the reported criteria, including permeability of inulin $(<$ about $0.17 \mu \mathrm{l} / \mathrm{min} / \mathrm{cm}^{2}$ ) and electrical resistance (>about $40 \Omega \cdot \mathrm{cm}^{2}$ ) for the formation of tight junctions (Onoda et al. 1990). Moreover, we confirmed that $\mathrm{Na}^{+}-\mathrm{K}^{+}$ATPase was

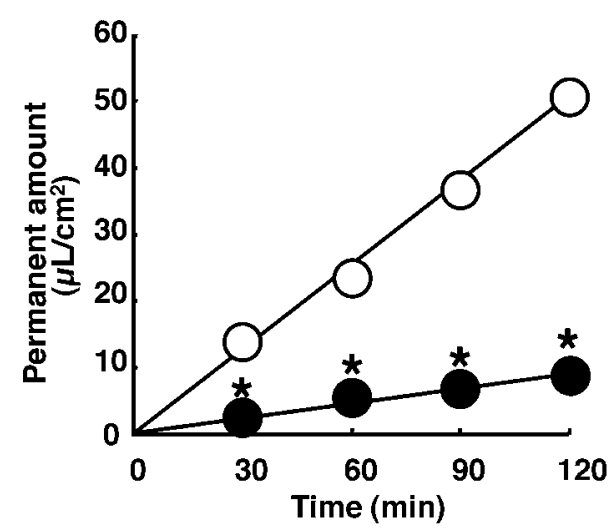

Figure 2 Permeability of $\left[{ }^{14} \mathrm{C}\right]$ inulin across rat Sertoli cells primarycultured on Matrigel-coated invasion chambers. Rat Sertoli cells were primary-cultured on Matrigel-coated invasion chambers. Permeability of $\left[{ }^{14} \mathrm{C}\right]$ inulin $(74 \mu \mathrm{g} / \mathrm{ml})$ was determined in the presence (closed circles) or absence (open circles) of Sertoli cells. Each result represents the mean \pm S.E.M. $(n=4) .{ }^{*}$ Indicates a significant difference from the permeability of $\left[{ }^{14} \mathrm{C}\right]$ inulin in the absence of Sertoli cells $(P<0.05)$. When the S.E.M. is not shown, it is smaller than the symbols. localized at the apical membrane of primary-cultured Sertoli cells by immunofluorescence analysis (data not shown). This result is consistent with the reported localization of $\mathrm{Na}^{+}-\mathrm{K}^{+}$ATPase in rat testicular tissue (Byers \& Graham 1990). Therefore, we evaluated the basolateral membrane uptake of $\left[{ }^{3} \mathrm{H}\right]$ carnitine using the cells cultured in Matrigel-coated invasion chambers.

The concentration dependence of carnitine uptake from the basolateral membrane was measured in the range from $10 \mu \mathrm{M}$ to $10 \mathrm{mM}$. As shown in Fig. 3, uptake of $\left.{ }^{3} \mathrm{H}\right]$ carnitine $(11.4 \mathrm{nM})$ was reduced by unlabeled carnitine in a concentration-dependent manner. Figure 4a shows the uptake of $\left[{ }^{3} \mathrm{H}\right]$ carnitine in the presence and in the absence of sodium ions. When sodium ions were replaced with $\mathrm{Li}^{+}$or $\mathrm{N}$-methylglucamine ${ }^{+}$, uptake of carnitine was significantly decreased. In Fig. $4 b$, the inhibitory effects of carnitine analogues and a cationic drug on $\left[{ }^{3} \mathrm{H}\right]$ carnitine uptake across the basolateral membrane of the primary cultured Sertoli cells are shown. Carnitine analogues, acetylcarnitine $(100 \mu \mathrm{M})$ and gamma-butyrobetaine $(100 \mu \mathrm{M})$, and the cationic drug, quinidine $(500 \mu \mathrm{M})$, significantly decreased the uptake of carnitine. These results demonstrated that carnitine uptake by Sertoli cells across the basolateral membrane is mediated by an $\mathrm{Na}^{+}$-dependent transporter that is sensitive to carnitine analogues and cationic drug(s).

\section{Expression assay of carnitine transporter and carnitine palmitoyltransferase I by RT-PCR}

To clarify which transporter mediates carnitine uptake by the Sertoli cells, we examined expression of previously known carnitine transporters, OCTN1, 2 and $\mathrm{ATB}^{\mathrm{O},+}$, in rat whole testis and the primary-cultured Sertoli cells by

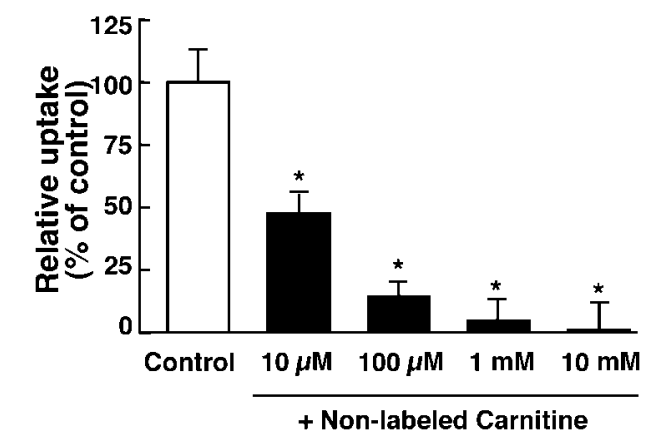

Figure 3 Concentration dependence of basolateral uptake of $\mathrm{L}-\left[{ }^{3} \mathrm{H}\right]$ carnitine in rat primary-cultured Sertoli cells. Basolateral uptake of L- $\left[{ }^{3} \mathrm{H}\right]$ carnitine $(11.4 \mathrm{nM})$ in rat Sertoli cells primary-cultured on Matrigel-coated invasion chambers was measured for $30 \mathrm{~min}$ in transport buffer ( $\mathrm{pH} 7.4$ ) in the presence (closed column) or absence (open column) of non-labeled carnitine. The cells were preincubated for $20 \mathrm{~min}$ at $37^{\circ} \mathrm{C}$ in the transport buffer $(\mathrm{pH} \mathrm{7.4)}$. Results were obtained by subtracting the uptakes of $\left[{ }^{14} \mathrm{C}\right]$ inulin $(156 \mu \mathrm{g} / \mathrm{ml})$ at $30 \mathrm{~min}$, and expressed as a percentage of control uptake measured in the absence of non-labeled carnitine. Each result represents the mean \pm S.E.M. $(n=4)$. ${ }^{*}$ Indicates a significant difference from the control $(P<0.05)$. 


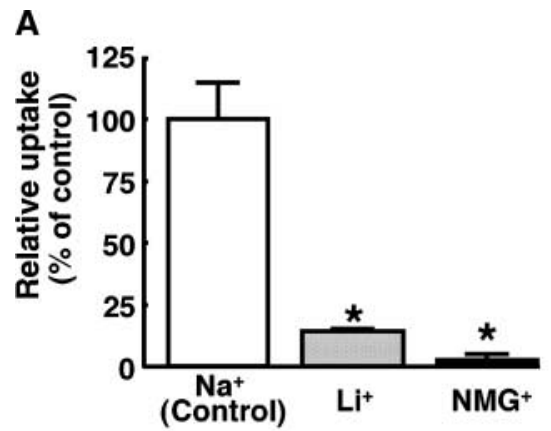

B

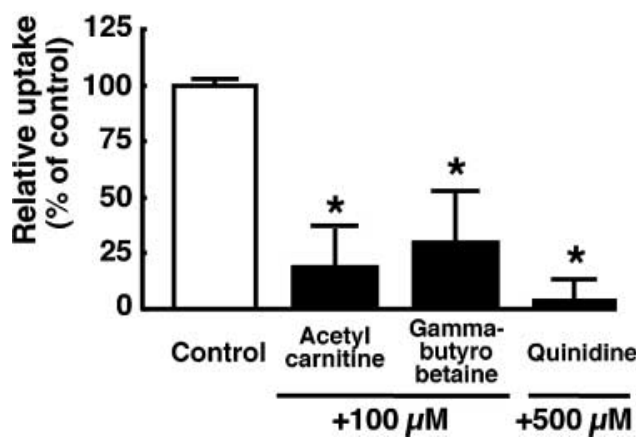

Figure 4 Sodium dependence and inhibitory effects of several compounds on basolateral uptake of $\mathrm{L}-\left[{ }^{3} \mathrm{H}\right]$ carnitine in rat primary-cultured Sertoli cells. (a)Basolateral uptake of L- $\left.{ }^{3} \mathrm{H}\right]$ carnitine (11.4 nM) in rat Sertoli cells primary-cultured on Matrigel-coated invasion chambers was measured for $30 \mathrm{~min}$ in transport buffer $(\mathrm{pH} 7.4)$ in the presence (open column) or absence of $\mathrm{Na}^{+}$. $\mathrm{Na}^{+}$was replaced with lithium $\left(\mathrm{Li}^{+}\right.$, dotted column) or $\mathrm{N}$-methylglucamine $\left(\mathrm{NMG}^{+}\right.$, closed column). The cells were preincubated for $20 \mathrm{~min}$ at $37^{\circ} \mathrm{C}$ in the transport buffer $(\mathrm{pH} 7.4)$. Results were obtained by subtracting the uptakes of $\left[{ }^{14} \mathrm{C}\right]$ inulin $(156 \mu \mathrm{g} / \mathrm{ml})$ at $30 \mathrm{~min}$, and expressed as a percentage of the uptake in the presence of $\mathrm{Na}^{+}$(control). (b)Basolateral uptake of $\mathrm{L}-\left[{ }^{3} \mathrm{H}\right]$ carnitine $(11.4 \mathrm{nM})$ in rat primary-cultured Sertoli cells was measured for $30 \mathrm{~min}$ in transport buffer $(\mathrm{pH} \mathrm{7.4)}$ in the presence (open column) or absence (closed column) of various compounds. Concentrations of these compounds are indicated in the figure. The cells were preincubated for $20 \mathrm{~min}$ at $37^{\circ} \mathrm{C}$ in the transport buffer (pH 7.4). Results were obtained by subtracting the uptakes of $\left[{ }^{14} \mathrm{C}\right]$ inulin $(156 \mu \mathrm{g} / \mathrm{ml})$ at $30 \mathrm{~min}$, and expressed as a percentage of the uptake in the absence of inhibitors (control). Each result represents the mean \pm S.E.M. $(n=4) .{ }^{*}$ Indicates a significant difference from the control $(P<0.05)$.

means of RT-PCR analysis. As shown in Fig. 5a, OCTN1 and OCTN2 were both expressed in rat testis and Sertoli cells. In contrast, low-affinity carnitine transporter $\mathrm{ATB}^{\mathrm{O},+}$ was detected in rat testis tissue, but not in primary-cultured Sertoli cells.

To explore the physiological role of carnitine in testicular cells, we examined expression of carnitine palmitoyltransferase I (CPT I), which is the rate-limiting enzyme of fatty acid oxidation (McGarry \& Brown 1997), in cultured Sertoli and germ cells by RT-PCR. As shown in Fig. 5b, both subtypes of CPT I, L-CPT I and M-CPT I, were detected in both cultured Sertoli and germ cells. In this culture system, phosphoglycerate kinase (PGK) mRNA
A

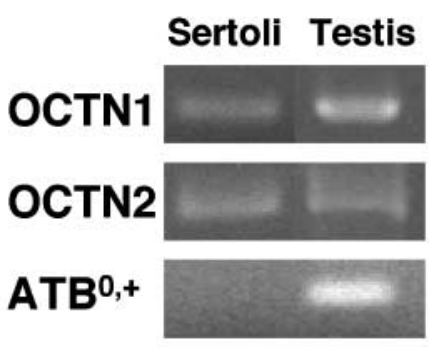

B

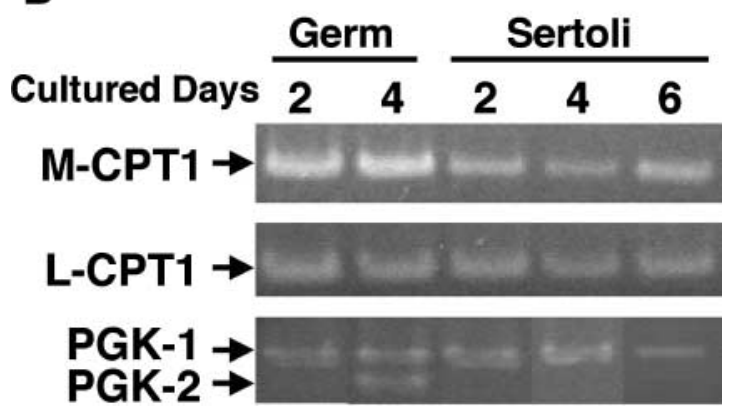

Figure 5 Expression of carnitine transporters and carnitine palmitoyltransferase I in testicular cells evaluated by RT-PCR analysis. The specific primers described under Materials and Methods were used for determining (a) expression of carnitine transporters in testicular tissue and Sertoli cells primary-cultured for 6 weeks, and (b) expression of carnitine palmitoyltransferase I (CPT I) in rat germ cells and Sertoli cells primary-cultured for 2 and 4 weeks or 2, 4 and 6 weeks, respectively.

switches from somatic-type PGK-1 to sperm-type PGK-2 in germ cells during development across the pachytene spermatocyte stage in vivo (Tamaru et al. 1990). The expression of PGK-2 was increased in 4-day-cultured germ cells compared with 2-day-cultured germ cells (Fig. 5b). Additionally, PGK-2 was not detected in Sertoli cells (Fig. 5b), suggesting that contamination of germ cells in the obtained Sertoli cells was negligible. Therefore, it was demonstrated that both M-CPT I and L-CPT I are expressed in both germ and Sertoli cells. Furthermore, expression of OCTN2 was demonstrated in germ cells by RT-PCR analysis (data not shown) as well as Sertoli cells.

\section{Western blotting analysis for OCTN2 in testis and Sertoli cells}

We performed Western blotting analysis using antiOCTN2 antibody to clarify the expression of OCTN2 protein in Sertoli cells (Fig. 6). A band of $70 \mathrm{kDa}$ was detected in both testis and cultured Sertoli cells, and this is larger than the size of rat OCTN2 protein estimated from the amino acid sequence, $63 \mathrm{kDa}$ (Wu et al. 1999). So, the OCTN2 in Sertoli cells might be glycosylated. Further, the size of the band corresponded to that in kidney, where rat OCTN2 is expressed (Tamai et al. 2001). 


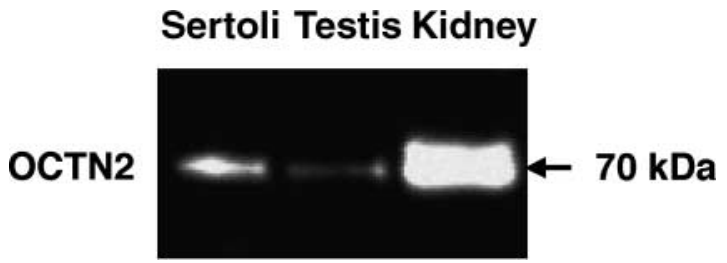

Figure 6 Western blotting analysis for OCTN2 in rat testis and Sertoli cells. Expression of OCTN2 in rat whole testis, primary-cultured Sertoli cells and kidney (positive control) was examined by Western blotting analysis with affinity-purified anti-OCTN2 antibody. Ten microgramF aliquots of protein for rat testis, Sertoli cells and kidney were applied and analyzed.

Accordingly, it was concluded that OCTN2 protein was expressed in Sertoli cells, as well as whole testis in rat.

\section{Discussion}

We examined carnitine transport in Sertoli cells, which constitute the BTB. First, we demonstrated that the primary-cultured Sertoli cells used in the present study form tight junctions, by means of electrical resistance and inulin permeability measurements (Fig. 2), and we established the absence of contamination with spermatogenic cells by confirming the selective expression of markers for the germ cells, such as PGK gene. These results are consistent with the idea that rat Sertoli cells cultured on a Matrigel-coated invasion chamber are useful for evaluating carnitine uptake at the basolateral membrane of Sertoli cells, which is an important step in the supply of carnitine to testis.

Secondly, we demonstrated that carnitine uptake from the basolateral membrane of Sertoli cells was concentration- and $\mathrm{Na}^{+}$-dependent, and was inhibited by carnitine analogues and by a cationic drug. Although the concentration dependence was not analyzed kinetically, the results in Fig. 3 suggest that the half-saturation concentration for carnitine uptake was about $10 \mu \mathrm{M}$. The estimated half-saturation concentration is comparable to the $\mathrm{Km}$ values of human and rat OCTN2 for carnitine transport, $4.3 \mu \mathrm{M}$ and $14.8 \mu \mathrm{M}$ respectively (Tamai et al. 1998, Wu et al. 1999). Inhibitors of OCTN2, acetylcarnitine, gamma-butyrobetaine and quinidine, also significantly reduced carnitine uptake across the basolateral membrane of Sertoli cells. Furthermore, expression of OCTN2 was observed in Sertoli cells and whole testis tissues by RTPCR and Western blotting analysis (Fig. 5a and 6). All of these observations suggested that carnitine uptake across the basolateral membrane of Sertoli cells is mediated by OCTN2.

OCTN2 is functionally expressed at blood-tissue barriers, such as the blood-brain barrier (Kido et al. 2001, Inano et al. 2003) and the blood-placenta barrier (Lahjouji et al. 2004, Shekhawat et al. 2004). Accordingly, OCTN2 may play a role in transferring carnitine across these tissue barriers. In the present study, an isoform of OCTN2, OCTN1 was also expressed in Sertoli cells and whole testis (Fig. 5a). Human and mouse OCTN1 transported carnitine, while rat OCTN1 did not exhibit carnitine transport activity ( $\mathrm{Wu}$ et al. 2000). The low-affinity carnitine transporter $\mathrm{ATB}^{0,+}$ (Nakanishi et al. 2001) was not detected in Sertoli cells (Fig. 5a). These results suggested that OCTN1 and $\mathrm{ATB}^{0,+}$ may not be involved in carnitine transport in rat Sertoli cells. OCTN3 and CT2, which are carnitine transporters expressed in mouse and human testis, may not be important for basolateral transport of carnitine in rat Sertoli cells, since $\mathrm{Na}^{+}$-independent carnitine transporters like OCTN3 or CT2 were not detected as shown in Fig. 4a. The lack of those types of transporters in rat Sertoli cells was not examined, since no corresponding rat molecules have been identified yet. In humans, sodium-dependent OCTN2 is expressed in testis (Tamai et al. 1998), and human carnitine transporter CT2, which is a sodium-independent carnitine transporter, is also expressed in testis (Enomoto et al. 2002). Therefore, multiple transporters that have different functionality should contribute to transport of carnitine in human Sertoli cells.

OCTN2 is a multi-specific transporter, transporting cationic compounds as well as carnitine, and various drugs, such as verapamil, mepyramine and quinidine, which are strong inhibitors of OCTN2-mediated transport of carnitine (Ohashi et al. 1999, 2001, 2002). Accordingly, carnitine supply to the testis by OCTN2 might be disturbed by these cationic compounds. Furthermore, OCTN2 may mediate entry of those cationic xenobiotics to the testis from the systemic circulation, suggesting that OCTN2 might be relevant to the testicular toxicity of externally administered drugs/xenobiotics. Additionally, we examined whether carnitine which was taken up by the Sertoli cells could permeate to the apical side across Sertoli cells by measuring permeation of carnitine from the basolateral to the apical compartment by using rat Sertoli cells cultured on a Matrigel-coated invasion chamber. Permeability clearance of $\left[{ }^{3} \mathrm{H}\right]$ carnitine $\left(0.69 \pm 0.05 \mu \mathrm{l} / \mathrm{min} / \mathrm{cm}^{2}\right)$ was higher than that of $\left[{ }^{14} \mathrm{C}\right]$ inulin $\left(0.14 \pm 0.01 \mu \mathrm{l} / \mathrm{min} / \mathrm{cm}^{2}\right)$. Although molecular weights of carnitine and inulin were different, 161 and about 4000 respectively, and their paracellular permeabilities should be different, observed fivetimes higher permeability of carnitine than inulin indicates that carnitine taken up by the Sertoli cells are supplied to the seminiferous tubular fluid across the BTB.

It was reported that both M-CPT I and L-CPT I, which are rate-limiting enzymes for fatty acid oxidation (McGarry \& Brown 1997), are expressed in rat and mouse testis (Brown et al. 1997). Adams et al. (1998) reported that M-CPT I is mainly expressed in spermatocytes and spermatids. In the present study, expression of M-CPT I was abundant in germ cells compared with Sertoli cells (Fig. 5b), and this result accords well with previous observations (Adams et al. 1998). In addition, other studies have indicated that germ cells contain the key enzyme for 
oxidation of fatty acids (Bajpai et al. 1998), and spermatogonia and spermatocytes exhibit relatively high rates of palmitate oxidation (Lin \& Fritz, 1972). Accordingly, carnitine should be essential for germ cells, though the mechanism of the supply of carnitine to germ cells has not been elucidated. OCTN2, which was expressed in germ cells, may be contributing to carnitine transport, although further studies are required to determine the relative contribution of OCTN2 in these cells.

Interestingly, we found that both L-CPT I and M-CPT I are expressed in Sertoli cells (Fig. 5b), suggesting that carnitine can be passed from the blood circulation to Sertoli cells, as well as germ cells. This speculation was supported by the findings that oxidation of fatty acids is likely to be the major energy source for Sertoli cells (Jutte et al. 1985) and that L-carnitine treatment significantly reduced non-esterified fatty acids in cultured rat Sertoli cells (Palmero et al. 2000).

In conclusion, primary-cultured Sertoli cells are a useful tool for studying transport across the basolateral membrane of Sertoli cells, and we established that uptake of carnitine at the basolateral membrane of these cells is mainly mediated by $\mathrm{Na}^{+}$-dependent transporter, OCTN2 .

\section{Acknowledgements}

The authors thank Prof. Y Nakanishi and Dr A Shiratsuchi for their helpful advice on primary culture of rat Sertoli cells, and Mr Ryo Kato for his contribution to primary culture of rat Sertoli cells. This investigation was supported in part by a Grant-in-Aid for Scientific Research from the Ministry of Education, Culture, Sports, Science, and Technology, Japan, and a research grant from AstraZeneca.

\section{References}

Adams SH, Esser V, Brown NF, Ing NH, Johnson L, Foster DW \& McGarry JD 1998 Expression and possible role of muscle-type carnitine palmitoyltransferase I during sperm development in the rat. Biology of Reproduction 59 1399-1405.

Bajpai M, Gupta G, Jain SK \& Setty BS 1998 Lipid metabolizing enzymes in isolated rat testicular germ cells and changes associated with meiosis. Andrologia 30 311-315.

Bremer J 1983 Carnitine-metabolism and functions. Physiological Reviews 63 1420-1480.

Brown NF, Hill JK, Esser V, Kirkland JL, Corkey BE, Foster DW \& McGarry JD 1997 Mouse white adipocytes and 3T3-L1 cells display an anomalous pattern of carnitine palmitoyltransferase (CPT) I isoform expression during differentiation. Biochemical Journal 327 $225-231$.

Byers S \& Graham R 1990 Distribution of sodium-potassium ATPase in the rat testis and epididymis. American Journal of Anatomy $\mathbf{1 8 8}$ $31-43$.

Casillas ER 1972 The distribution of carnitine in male reproductive tissues and its effect on palmitate oxidation by spermatozoal particles. Biochimica et Biophysica Acta 280 545-551.

Casillas ER \& Chaipayungpan S 1979 The distribution of carnitine and acetylcarnitine in the rabbit epididymis and the carnitine content of rabbit spermatozoa during maturation. Journal of Reproduction and Fertility $\mathbf{5 6}$ 439-444.
Dorrington JH \& Fritz IB 1975 Cellular localization of $5 \alpha$-reductase and $3 \alpha$-hydroxysteroid dehydrogenase in the seminiferous tubule of the rat testis. Endocrinology 96 879-889.

Enomoto A, Wempe MF, Tsuchida H, Shin HJ, Cha SH, Anzai N, Goto A, Sakamoto A, Niwa T, Kanai Y, Anders MW \& Endou H 2002 Molecular identification of a novel carnitine transporter specific to human testis. Journal of Biological Chemistry 277 $36262-36271$.

Hinton BT, Snoswell AM \& Setchell BP 1979 The concentration of carnitine in the luminal fluid of the testis and epididymis of the rat and some other mammals. Journal of Reproduction and Fertility $\mathbf{5 6}$ 105-111.

Hinton BT, Brooks DE, Dott HM \& Setchell P 1981 Effects of carnitine and some related compounds on the motility of rat spermatozoa from the caput epididymidis. Journal of Reproduction and Fertility 61 59-64.

Inano A, Sai Y, Nikaido H, Hasimoto N, Asano M, Tsuji A \& Tamai I 2003 Acetyl-L-carnitine permeability across the blood-brain barrier and involvement of carnitine transporter OCTN2. Biopharmaceutics and Drug Disposition 24 357-365.

Jeulin C \& Lewin LM 1996 Role of free L-carnitine and acetyl-L-carnitine in post-gonadal maturation of mammalian spermatozoa. Human Reproduction Update 2 87-102.

Jutte NH, Eikvar L, Levy FO \& Hansson V 1985 Metabolism of palmitate in cultured rat Sertoli cells. Journal of Reproduction and Fertility 73 497-503.

Kato R, Maeda T, Akaike T \& Tamai I 2005 Nucleoside transport at the blood-testis barrier studied with primary-cultured Sertoli cells. Journal of Pharmacology and Experimental Therapeutics 312 $601-608$.

Kido Y, Tamai I, Ohnari A, Sai Y, Kagami T, Nezu J, Nikaido H, Hashimoto N, Asano M \& Tsuji A 2001 Functional relevance of carnitine transporter OCTN2 to brain distribution of L-carnitine and acetyl-L-carnitine across the blood-brain barrier. Journal of Neurochemistry 79 959-969.

Lahjouji K, Elimrani I, Lafond J, Leduc L, Qureshi IA \& Mitchell GA 2004 L-carnitine transport in human placental brush-border membranes mediated by the sodium-dependent organic cation transporter OCTN2. American Journal of Physiology $\mathbf{2 8 7}$ C263-C269.

Lin CH \& Fritz LB 1972 Studies on spermatogenesis in rats. IV. Rates of oxidation of palmitate and pyruvate by various testicular cell populations. Canadian Journal of Biochemistry 50 963-968.

Lowry OH, Rosebrough NJ, Farr AL \& Randall RJ 1951 Protein measurement with the Folin phenol reagent. Journal of Biological Chemistry 193 265-275.

Marquis NR \& Fritz IB 1965 The distribution of carnitine, acetylcarnitine, and carnitine acetyltransferase in rat tissues. Journal of Biological Chemistry 240 2193-2196.

Matalliotakis I, Koumantaki Y, Evageliou A, Matalliotakis G, Goumenou A \& Koumantakis E 2000 L-carnitine levels in the seminal plasma of fertile and infertile men: correlation with sperm quality. International Journal of Fertility and Women's Medicine $\mathbf{4 5}$ 236-240.

Mather JP, Attie KM, Woodruff TK, Rice GC \& Phillips DM 1990 Activin stimulates spermatogonial proliferation in germ-Sertoli cell cocultures from immature rat testis. Endocrinology 127 3206-3214.

McGarry JD \& Brown NF 1997 The mitochondrial carnitine palmitoyltransferase system. From concept to molecular analysis. European Journal of Biochemistry 244 1-14.

Mizuno K, Shiratsuchi A, Masamune Y \& Nakanishi Y 1996 The role of Sertoli cells in the differentiation and exclusion of rat testicular germ cells in primary culture. Cell Death and Differentiation 3 119-123.

Nagao Y 1989 Viability of meiotic prophase spermatocytes of rats is facilitated in primary culture of dispersed testicular cells on collagen gel by supplementing epinephrine or norepinephrine: evidence that meiotic prophase spermatocytes complete meiotic 
divisions in vivo. In Vitro Cellular \& Developmental Biology 25 1088-1098.

Nakanishi T, Hatanaka T, Huang W, Prasad PD, Leibach FH, Ganapathy ME \& Ganapathy V $2001 \mathrm{Na}^{+}$- and $\mathrm{Cl}^{-}$-coupled active transport of carnitine by the amino acid transporter $\mathrm{ATB}^{\mathrm{O},+}$ from mouse colon expressed in HRPE cells and Xenopus oocytes. Journal of Physiology 532 297-304.

Nezu J, Tamai I, Oku A, Ohashi R, Yabuuchi H, Hashimoto N, Nikaido H, Sai Y, Koizumi A, Shoji Y, Takada G, Matsuishi T, Yoshino M, Kato H, Ohura T, Tsujimoto G, Hayakawa J, Shimane M \& Tsuji A 1999 Primary systemic carnitine deficiency is caused by mutations in a gene encoding sodium ion-dependent carnitine transporter. Nature Genetics 21 91-94.

Ohashi R, Tamai I, Yabuuchi H, Nezu J, Oku A, Sai Y, Shimane M \& Tsuji A $1999 \mathrm{Na}^{+}$-dependent carnitine transport by organic cation transporter (OCTN2): its pharmacological and toxicological relevance. Journal of Pharmacology and Experimental Therapeutics $291778-784$.

Ohashi R, Tamai I, Nezu J, Nikaido H, Hashimoto N, Oku A, Sai Y, Shimane M \& Tsuji A 2001 Molecular and physiological evidence for multifunctionality of carnitine/organic cation transporter OCTN2. Molecular Pharmacology 59 358-366.

Ohashi R, Tamai I, Inano A, Katsura M, Nezu J, Sai Y \& Tsuji A 2002 Studies on functional sites of organic cation/carnitine transporter OCTN2 (SLC22A5) using a Ser467Cys mutant protein. Journal of Pharmacology and Experimental Therapeutics 302 1286-1294.

Onoda M, Suárez-Quian CA, Djakiew D \& Dym M 1990 Characterization of Sertoli cells cultured in the bicameral chamber system: relationship between formation of permeability barriers and polarized secretion of transferrin. Biology of Reproduction 43 672-683.

Palmero S, Bottazzi C, Costa M, Leone M \& Fugassa E 2000 Metabolic effects of L-carnitine on prepubertal rat Sertoli cells. Hormone and Metabolic Research 32 87-90.

Ramsay RR, Gandour RD \& van der Leij FR 2001 Molecular enzymology of carnitine transfer and transport. Biochimica et Biophysica Acta $154621-43$.

Sekine T, Kusuhara H, Utsunomiya-Tate N, Tsuda M, Sugiyama $\mathbf{Y}$, Kanai Y \& Endou H 1998 Molecular cloning and characterization of high-affinity carnitine transporter from rat intestine. Biochemical and Biophysical Research Communications 251 586-591.

Shekhawat PS, Yang HS, Bennett MJ, Carter AL, Matern D, Tamai I \& Ganapathy V 2004 Carnitine content and expression of mitochondrial \{beta\}-oxidation enzymes in placentas of wild-type $($ OCTN2 $+/+)$ and OCTN2 null (OCTN2 $-/-)$ mice. Pediatric Research 56 323-328.

Shiratsuchi A, Umeda M, Ohba Y \& Nakanishi Y 1997 Recognition of phosphatidylserine on the surface of apoptotic spermatogenic cells and subsequent phagocytosis by Sertoli cells of the rat. Journal of Biological Chemistry 272 2354-2358.
Tamai I, Ohashi R, Nezu J, Yabuuchi H, Oku A, Shimane M, Sai Y \& Tsuji A 1998 Molecular and functional identification of sodium ion-dependent, high affinity human carnitine transporter OCTN2. Journal of Biological Chemistry 273 20378-20382.

Tamai I, Ohashi R, Nezu J, Sai Y, Kobayashi D, Oku A, Shimane M \& Tsuji A 2000 Molecular and functional characterization of organic cation/carnitine transporter family in mice. Journal of Biological Chemistry 275 40064-40072.

Tamai I, China K, Sai Y, Kobayashi D, Nezu J, Kawahara E \& Tsuji A $2001 \mathrm{Na}^{+}$-coupled transport of L-carnitine via high-affinity carnitine transporter OCTN2 and its subcellular localization in kidney. Biochimica et Biophysica Acta 1512 273-284.

Tamai I, Nakanishi T, Kobayashi D, China K, Kosugi Y, Nezu J, Sai Y \& Tsuji A 2004 Functional characterization and renal apical membrane localization of organic cation transporter OCTN1 (SLC22A4). Molecular Biopharmaceutics 157-66.

Tamaru M, Nagao Y, Taira M, Tatibana M, Masamune Y \& Nakanishi Y 1990 Selective activation of testis-specific genes in cultured rat spermatogenic cells. Biochimica et Biophysica Acta 1049 $331-338$

Vicari E \& Calogero AE 2001 Effects of treatment with carnitines in infertile patients with prostato-vasiculo-epididymitis. Human Reproduction 16 2338-2342.

Wu X, Huang W, Prasad PD, Seth P, Rajan DP, Leibach FH, Chen J, Conway SJ \& Ganapathy V 1999 Functional characteristics and tissue distribution pattern of organic cation transporter 2 (OCTN2), an organic cation/carnitine transporter. Journal of Pharmacology and Experimental Therapeutics 290 1482-1492.

Wu X, George RL, Huang W, Wang H, Conway SJ, Leibach FH \& Ganapathy V 2000 Structural and functional characteristics and tissue distribution pattern of rat OCTN1, an organic cation transporter, cloned from placenta. Biochimica et Biophysica Acta 1466 315-327.

Yabuuchi H, Tamai I, Nezu J, Sakamoto K, Oku A, Shimane M, Sai Y \& Tsuji A 1999 Novel membrane transporter OCTN1 mediates multispecific, bi-directional, and $\mathrm{pH}$-dependent transport of organic cations. Journal of Pharmacology and Experimental Therapeutics 289 768-773.

Yokogawa K, Higashi Y, Tamai I, Nomura M, Hashimoto N, Nikaido H, Hayakawa J, Miyamoto K \& Tsuji A 1999 Decreased tissue distribution of L-carnitine in juvenile visceral steatosis mice. Journal of Pharmacology and Experimental Therapeutics 289 224-230.

Received 4 October 2004

First decision 5 November 2004

Revised manuscript received 12 February 2005

Accepted 3 March 2005 